\title{
Gambaran Histopatologi Limpa Tikus Putih yang Diberi Deksametason dan Vitamin E
}

\author{
(HISTOPATHOLOGICAL OF WHITE RATS SPLEEN THAT \\ GIVEN DEXAMETHASONE AND VITAMIN E)
}

\author{
Elsa Hidayati ${ }^{1}$, I Ketut Berata ${ }^{2}$, Samsuri $^{3}$, I Made Merdana ${ }^{3^{*}}$, Luh Made Sudimartini ${ }^{3}$ \\ ${ }^{1}$ Praktisi Dokter Hewan di Kediri Jawa Timur ${ }^{2}$ Laboratorium Patologi Veteriner \\ ${ }^{3}$ Laboratorium Farmakologi dan Farmasi Veteriner \\ Fakultas Kedokteran Hewan, Universitas Udayana \\ Jalan PB. Sudirman Denpasar, Bali Telp. 0361-223791 Faks (0361) 223791 \\ *Email: imade_merdana@unud.ac.id
}

\begin{abstract}
ABSTRAK
Deksametason merupakan obat kortikosteroid golongan glukokortikoid yang berfungsi sebagai anti-inflamasi dan imunosupresan. Efek terapi dari obat ini adalah mengurangi respon radang dan menekan sistem imun. Limpa merupakan organ yang mengkoordinasi sistem imun, sehingga penggunaan deksametason secara berkepanjangan akan berefek pada limpa. Sebagai upaya mencegah efek deksametason ke limpa, maka dibutuhkan antioksidan. Vitamin E merupakan vitamin yang larut dalam lemak dan bertindak sebagai antioksidan. Penelitian ini menggunakan rancangan acak lengkap, dimana 25 ekor tikus putih jantan, dibagi menjadi 5 kelompok perlakuan. Kontrol negatif diberi pakan dan minum. Deksametason $\left(\operatorname{Harsen}^{\circledR}\right.$ ) diberikan secara injeksi subkutan $0,13 \mathrm{mg} / \mathrm{kg}$ BB pada perlakuan kontrol positif, P1, P2 dan P3. Vitamin E diberikan peroral pada perlakuan P1 $(100 \mathrm{mg} / \mathrm{kg}$ BB), P2 (150 mg/kg BB) dan P3 (200 mg/kg BB). Setelah 2 minggu perlakuan, semua sampel diterminasi dan diambil organ limpa untuk dibuat preparat histopatologi. Variabel yang diperiksa meliputi perdarahan dan nekrosis. Penelitian menunjukkan terjadi nekrosis pada kontrol positif, sedangkan P1, P2, P3 mengalami perbaikan kerusakan namun tidak signifikan. Perlakuan P2 menunjukkan hasil paling baik dalam mengurangi efek deksametason. Kesimpulan dari penelitian ini adalah deksametason mempengaruhi gambaran histopatologi limpa tikus putih dan Vitamin E dosis $150 \mathrm{mg} / \mathrm{kg}$ BB dapat memperlihatkan perbaikan kerusakan jaringan limpa yang lebih baik vitamin $\mathrm{E}$ dosis $100 \mathrm{mg} / \mathrm{kg} \mathrm{BB}$ dan $200 \mathrm{mg} / \mathrm{kg} \mathrm{BB}$.
\end{abstract}

Kata kunci: antioksidan; deksametason; limpa; nekrosis; vitamin E

\section{ABSTRACT}

Dexamethasone is a corticosteroid drug from the class of glucocorticosteroids that has antiinflammation and immunosuppressant effect. This drug has therapeutic effect such as immunosuppressive and reducing the inflammatory response. Spleen is an organ of the immune system, so that when used dexamethasone in the long term and large doses can affect the spleen. To prevent dexamethason effect on spleen, provision of antioxidants is required. Vitamin E is a fat soluble vitamin that acted as antioxidant. This study used complete randomized design. Sample of this experiment were 25 male rats divided randomly into 5 groups. Negative control were given standards food and drink. Dexamethasone administrated by subcutaneous injection $0,13 \mathrm{mg} / \mathrm{kg} \mathrm{BW}$ in positive control group, P1, P2 and P3. Vitamin E administrated orally with following P1 (100 mg/kg BW), P2 $(150 \mathrm{mg} / \mathrm{kg} \mathrm{BW})$ and P3 (200 mg/kg BW). After 2 weeks intervention, all samples were terminated, then took the spleen to make histopatology preparation. The variables examined include hemorrhage and necrosis. From the results showed a positive control necrosis, whereas P1, P2, P3 improvements in spleen damage, but was not significant. P2 treatment showed the best results in reducing the effects of dexamethasone. From this study it can be concluded that the dexamethasone dose $0,13 \mathrm{mg} / \mathrm{kg} \mathrm{BW}$ has histopatology of spleen changes and vitamin E dose $150 \mathrm{mg} / \mathrm{kg}$ BW can repair spleen tissue damage is better than vitamin E dose $100 \mathrm{mg} / \mathrm{kg} \mathrm{BW}$ and $200 \mathrm{mg} / \mathrm{kg} \mathrm{BW}$.

Keywords: antioxidant; dexamethasone; spleen; necrosis; vitamin E 
Deksametason merupakan salah satu obat kortikosteroid yang masuk ke dalam kelompok glukokortikoid sintetik (Indayani et al., 2015). Glukokortikoid berfungsi untuk mengatur metabolisme karbohidrat, lemak, dan protein (Macfarlane et al., 2008). Sebagai obat kortikosteroid, deksametason berkhasiat sebagai imunosupresan dan antiinflamasi untuk mengobati berbagai kondisi radang (Samtani et al., 2005). Efek antiinflamasi dari yang bekerja dengan menghambat respons inflamasi dan menyebabkan apoptosis dari berbagai sel (Kadmiel dan Cidlowski, 2008). Pemberian deksametason dengan dosis $0,13 \mathrm{mg} / \mathrm{kg}$ BB dapat mengakibatkan kerusakan pada pankreas, hati dan ginjal (Dharma et al., 2015; Insani et al., 2015; Rabiah et al., 2015).

Limpa merupakan salah satu organ pertahanan tubuh. Limpa memiliki fungsi memfiltrasi darah dan mengkoordinasi respon imun. Secara histologi limpa terdiri dari 2 bagian yaitu stroma dan parenkim. Bagian stroma terdiri dari kapsula dan trabekula, sedangkan parenkim limpa terdiri dari pulpa putih merupakan sistem kekebalan untuk melawan infeksi dan pulpa merah bertugas membuang bahanbahan yang tidak diperlukan dari dalam darah seperti sel darah merah yang rusak (Guyton dan Hall, 2000). Pulpa merah terdiri dari sel makrofag, sel plasma, dan elemen darah; pulpa putih terdiri dari limfosit yang tersusun padat didalamnya dan arteri sentralis pada bagian tengahnya (Matheos et al., 2013). Pulpa putih ini merupakan jaringan limfatik yang menyebar di seluruh limpa sebagai nodulus limpa dan seperti selubung limfatik periarterial. Serabut retikuler dan sel retikuler membentuk jalinan stroma dalam tiga dimensi mengandung pecahan limfosit, makrofag dan sel lain mirip dengan yang terlihat pada limfoglandula (Setiasih et al., 2011).

Penelitian mengenai efek samping deksametason secara histopatologi pada organ limpa sudah pernah dilakukan, namun belum ada yang melaporkan bagaimana mengatasi efek samping dari deksametason tersebut. Oleh karena itu dalam penelitian ini dilakukan perlakuan berupa pemberian vitamin $\mathrm{E}$ yang diperkirakan dapat mengurangi efek samping yang ditimbulkan deksametason pada limpa.

Vitamin E merupakan vitamin larut dalam lemak yang berfungsi sebagai antioksidan yang tinggi (Brigelius-Flohe, 1999). Vitamin E dapat menghambat terjadinya proses peroksida lipid dengan cara memindahkan atom hidrogen kepada radikal peroksil (Bebas et al., 2016). Antioksidan dalam vitamin E akan bertindak sebagai garis pertama pertahanan terhadap peroksidasi lipid, melindungi membran sel dari serangan radikal bebas yang dapat menyebabkan terjadinnya penyakit seperti penyakit degeneratif, aterosklerosis, stres oksidatif, kanker, katarak dan lain sebagainya (Rizvi et al., 2014). Vitamin E juga berkontribusi dalam menyokong sistem imun yang baik sehingga resiko terkena berbagai penyakit dapat berkurang. Selain itu Vitamin E juga dapat mengurangi efek toksik penggunaan Methotrexate dalam kemoterapi pengobatan kanker (Dhanesha et al., 2015).

\section{METODE PENELITIAN}

\section{Objek Penelitian}

Yang digunakan adalah 25 ekor tikus putih jantan (Rattus norvegicus) yang berumur 2 - 3 bulan dengan berat badan 200-300 gram. yang didapatkan di kota Denpasar, Provinsi Bali yang dibagi 5 perlakuan dan masing-masing perlakuan menggunakan 5 ekor tikus putih. Sampel yang digunakan dalam penelitian ini adalah limpa tikus putih.

\section{Prosedur Penelitian}

Tikus dibagi menjadi lima kelompok secara acak yang terdiri dari kontrol negatif atau tanpa perlakuan, kontrol positif diberikan deksametason $0,13 \mathrm{mg} / \mathrm{kg}$ BB secara subkutan, dan perlakuan diberikan deksametason $0,13 \mathrm{mg} / \mathrm{kg}$ BB 
dengan variasi vitamin $\mathrm{E}$ bertingkat yaitu P1 (100 mg/kg BB peroral), P2 (150 $\mathrm{mg} / \mathrm{kg}$ BB peroral) dan P3 (200 mg/kg BB peroral), perlakuan ini masing-masing diberikan satu kali sehari selama 2 minggu.

\section{Pembuatan Sediaan Histopatologi}

Pada pembuatan sediaan histopatologi, lima kelompok tikus yang telah diberikan perlakuan selama 2 minggu akan diambil organ limpanya untuk selanjutnya dilakukan pembuatan preparat dengan metode pewarnaan HematoksilinEosin (HE). Sampel organ limpa tersebut diambil dan dipotong $1 \times 1 \times 1 \mathrm{~cm}$, kemudian direndam dalam larutan neutral buffer formalin (NBF) 10\%. Sampel organ selanjutnya diperkecil lagi dengan irisan tipis untuk disimpan dalam tissue cassate dan dilakukan fiksasi dalam larutan NBF. Setelah difiksasi, dilakukan proses dehidrasi dan clearing dengan satu sesi larutan yang terdiri dari: alkohol 70\%, alkohol 80\%, alkohol 90\%, alkohol absolut, toluene dan parafin, secara bertahap dalam waktu satu hari. Sampel organ di blocking dengan embedding set yang dituangi parafin cair kemudian didinginkan. Blok yang sudah dingin di sectioning menggunakan microtome dengan ketebalan $\pm 4-5$ mikron. Proses terakhir adalah pewarnaan dengan metode Harris Hematoxylyin-Eosin dan mounting media.

Preparat histopatologi diamati di bawah mikroskop masing-masing pada 5 lapang pandang dengan perbesaran $100 \mathrm{X}$ dan 400X. Limpa yang diperiksa secara histopatologi berdasarkan adanya perdarahan dan nekrosis folikel diskoring. Untuk hasil pemeriksaan perdarahan diberi skor yakni 0 (Normal, tidak ada perdarahan), 1 (Perdarahan ringan/fokal), 2 (Perdarahan sedang/multifokal), 3 (perdarahan berat/difusa). Untuk hasil
DOI:10.24843/bulvet.2018.v10.101.p03

pemeriksaan nekrosis yakni 0 (Tidak ada nekrosis), 1 (Nekrosis ringan/fokal), 2 (Nekrosis sedang/multifokal), 3 (Nekrosis berat/difusa).

\section{Analisis Data}

Dianalisis menggunakan program komputer SPSS (Statistical Product and Service Solutions). Pengaruh vitamin E terhadap limpa tikus putih yang diberi deksametason dianalisis dengan uji statistik nonparametik Kruskal-Wallis. Jika perubahan nyata $(\mathrm{P}<0,05)$, uji dilanjutkan dengan uji Mann-Whitney untuk mengetahui perbedaan pengaruh dosis vitamin $\mathrm{E}$ yang diberikan.

\section{HASIL DAN PEMBAHASAN}

\section{Hasil}

Hasil pemeriksaan histopatologi limpa tikus putih pada kontrol negatif (-) menunjukkan kesuluruhan limpa dari kelima tikus putih tidak mengalami nekrosa, namun terdapat perdarahan sedang. Pada kontrol positif nekrosa sedang paling banyak dan perdarahan sedang hampir di semua limpa.

Hasil pengamatan histopatologi limpa tikus putih (Rattus norvegicus) pada semua kelompok perlakuan tersaji pada Tabel 1 dan Tabel 2. Kelompok P2 merupakan kelompok yang secara pengamatan histopatologi memiliki gambaran yang paling baik. Nekrosis pada perlakuan P2 ini mengalami perbaikan yaitu terdapat tiga limpa yang mengalami nekrosis ringan, satu limpa nekrosis sedang, dan satu limpa tidak mengalami nekrosis. Untuk perdarahan kelima limpa mengalami perdarahan sedang hampir sama dengan perdarahan pada kontrol negatif.

Hasil pemeriksaan histopatologi dengan lesi perdarahan dan lesi nekrosis disajikan pada Gambar 1 sampai Gambar 5 . 
Tabel 1. Tabulasi hasil pemeriksaan histopatologi limpa tikus putih kategori perdarahan pada semua kelompok perlakuan.

\begin{tabular}{lcccc}
\hline Perlakuan & \multicolumn{4}{c}{ Kategori tingkat patologi (n=25) } \\
\cline { 2 - 5 } & $\begin{array}{c}\text { Normal /tidak } \\
\text { ada perdarahan }\end{array}$ & $\begin{array}{c}\text { Perdarahan } \\
\text { ringan/fokal }\end{array}$ & $\begin{array}{c}\text { Perdarahan } \\
\text { sedang/multifokal }\end{array}$ & $\begin{array}{c}\text { Perdarahan } \\
\text { berat/difusa }\end{array}$ \\
& $(0)$ & $(1)$ & $(2)$ & $(3)$ \\
\hline Kontrol (-) & - & - & 4 & 1 \\
Kontrol (+) & 1 & - & 4 & - \\
P1 & 3 & - & 2 & - \\
P2 & - & - & 5 & - \\
P3 & 2 & - & 3 & - \\
\hline
\end{tabular}

Tabel 2. Tabulasi hasil pemeriksaan histopatologi limpa tikus putih kategori nekrosis pada semua kelompok perlakuan.

\begin{tabular}{lcccc}
\hline \multirow{2}{*}{ Perlakuan } & \multicolumn{4}{c}{ Kategori tingkat patologi (n=25) } \\
\cline { 2 - 5 } & $\begin{array}{c}\text { Normal /tidak } \\
\text { ada perubahan }\end{array}$ & $\begin{array}{c}\text { Nekrosis } \\
\text { ringan/fokal }\end{array}$ & $\begin{array}{c}\text { Nekrosis } \\
\text { sedang/multifokal }\end{array}$ & $\begin{array}{c}\text { Nekrosis berat/difusa } \\
\text { (0) }\end{array}$ \\
\hline Kontrol (-) & 5 & $(1)$ & $(2)$ & - \\
Kontrol (+) & - & - & - & - \\
P1 & - & 1 & 5 & - \\
P2 & 1 & 3 & 4 & - \\
P3 & 1 & 1 & 1 & - \\
\hline
\end{tabular}

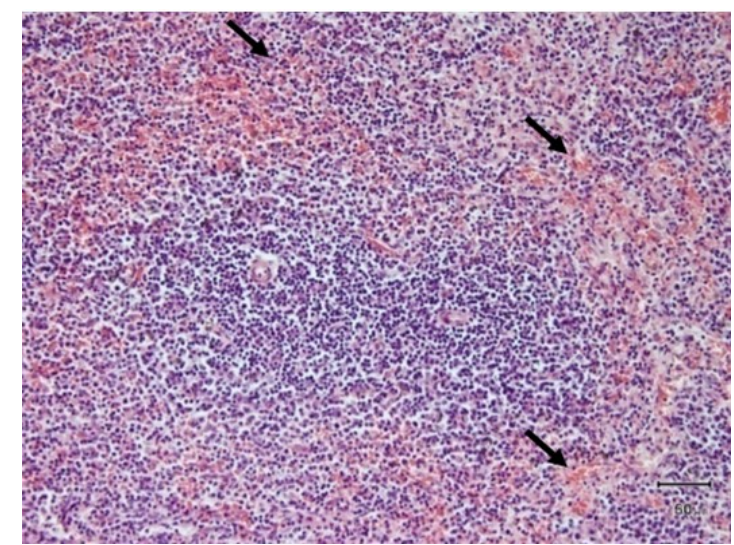

Gambar 1. Gambaran histopatologi limpa tikus putih pada kelompok kontrol negatif ditemukan adanya perdarahan yang bersifat sedang (multifokal) yang ditunjukkan oleh tanda panah hitam dan tidak terdapat nekrosis (HE, 200X.).

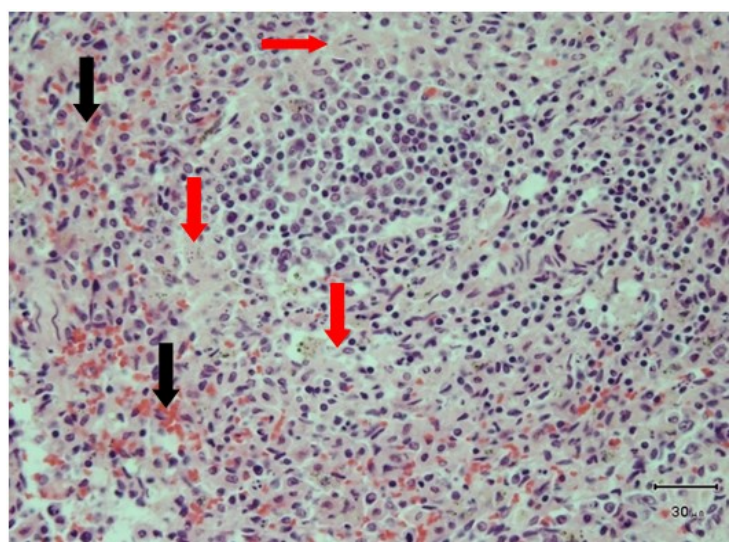

Gambar 2. Gambaran histopatologi limpa tikus putih pada kelompok kontrol positif ditemukan adanya nekrosis yang bersifat multifokal (tanda panah merah) dan perdarahan yang bersifat multifokal (tanda panah hitam) (HE, 400X.). 


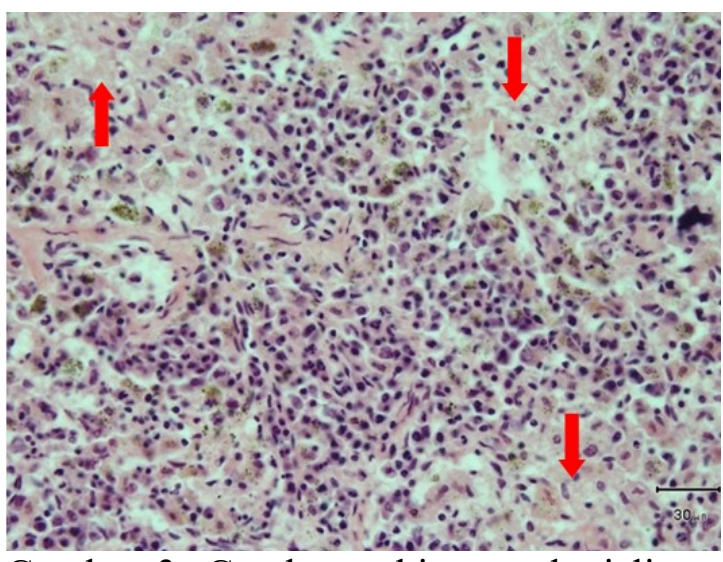

Gambar 3. Gambaran histopatologi limpa tikus putih pada kelompok P1 ditemukan adanya nekrosis yang bersifat multifokal (tanda panah merah) dan tidak terdapat perdarahan (HE, 400X.).

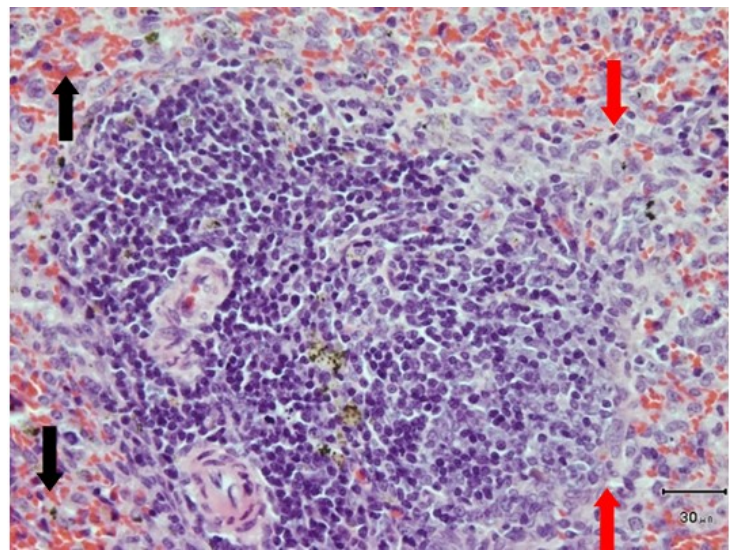

Gambar 4. Gambaran histopatologi limpa tikus putih pada kelompok P2 ditemukan adanya nekrosis yang bersifat lokal (tanda panah merah) dan perdarahan yang bersifat multifokal (tanda panah hitam) (HE, 400X.).

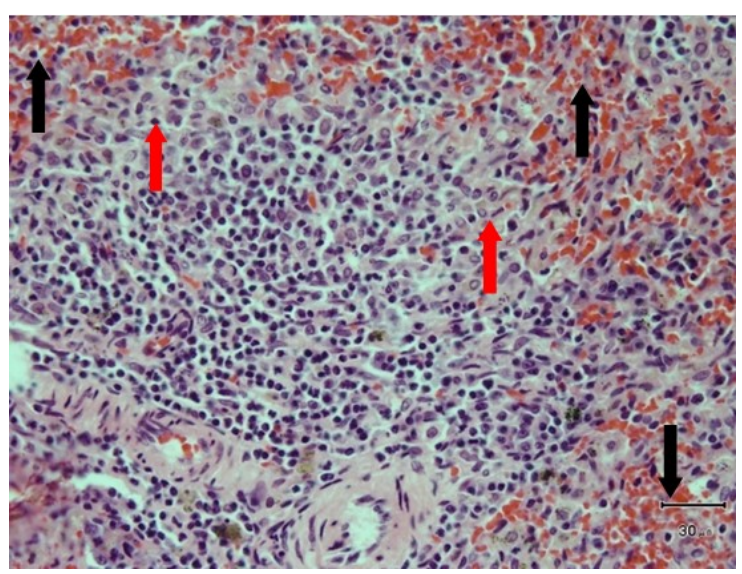

Gambar 5. Gambaran histopatologi limpa tikus putih pada kelompok P3 ditemukan adanya nekrosis yang bersifat lokal (tanda panah merah) dan perdarahan yang bersifat multifokal (tanda panah hitam) (HE, 400X.).

\section{Pembahasan}

Uji statistik Kruskal-Wallis terlihat bahwa perlakuan untuk perdarahan menunjukkan tidak ada perbedaan nyata $(\mathrm{P}>0,05)$ antara perlakuan kontrol negatif dengan kelompok perlakuan lain. Perlakuan untuk nekrosis terdapat perbedaan sangat nyata $(\mathrm{P}<0,01)$ antara kelompok kontrol negatif dengan kelompok perlakuan. Karena hanya kategori nekrosis yang terdapat perbedaan yang nyata antara kelompok kontrol dengan kelompok perlakuan, maka dilanjutkan dengan uji Mann-Whitney untuk mengetahui perbedaan pengaruh antar dosis vitamin $\mathrm{E}$ yang diberikan. Hasil uji Mann-Whitney untuk kategori nekrosis adalah antara kelompok kontrol negatif dengan kontrol positif dan P1 terdapat perbedaan yang sangat nyata $(\mathrm{P}<0.01)$, sedangkan antara kontrol negatif dengan P2 dan P3 terdapat perbedaan nyata $(\mathrm{P}<0,05)$. Kemudian antara kontrol positif dengan $\mathrm{P} 2$ terdapat perbedaan yang nyata $(\mathrm{P}<0,05)$, antara kontrol positif dengan $\mathrm{P} 1$ dan P3 tidak terdapat perbedaan nyata $(\mathrm{P}>0,05)$. Sedangkan $\mathrm{P} 1$ dengan $\mathrm{P} 2$ dan $\mathrm{P} 3$ tidak terdapat perbedaan nyata $(\mathrm{P}>0,05)$ dan P2 dengan P3 juga tidak terdapat perbedaan yang nyata $(\mathrm{P}>0,05)$.

Hasil pemeriksaan histopatologi dan uji statisik pada penelitian ini menunjukkan bahwa pemberian deksametason memberi efek samping pada limpa tikus putih, dimana-limpa kontrol negatif tidak mengalami nekrosis, namun setelah pemberian deksametason limpa mengalami nekrosis yang bersifat multifokal. Selanjutnya pemberian suplemen vitamin $\mathrm{E}$ terhadap efek samping deksametason $(0,13 \mathrm{mg} / \mathrm{kg} \quad \mathrm{BB})$ pada limpa tikus putih pada kategori nekrosis mengalami perbaikan sel. Dilihat dari hasil ini pada perlakuan kontrol positif yang diberi deksametason $0,13 \mathrm{mg} / \mathrm{kg} \quad \mathrm{BB}$ menunjukkan kerusakan ditandai dengan 
terjadinya nekrosis yang bersifat sedang atau multifokal. Untuk kategori perdarahan tidak menunjukkan adanya perbaikan.

Perdarahan pada penelitian ini hampir terjadi pada semua kelompok perlakuan. Pada kontrol negatif terjadi perdarahan yang paling parah dibanding perlakuan-perlakuan lain. Hal tersebut mungkin disebabkan oleh organ limpa sendiri merupakan organ yang berfungsi memfiltrasi darah dan bertugas membuang bahan-bahan yang tidak diperlukan dari dalam darah seperti sel darah merah yang rusak, selain itu limpa merupakan organ yang berperan memobilisasi darah bila aktivitas fisiologis meningkat (Guyton dan Hall, 2000). Perdarahan ini juga bisa diakibatkan tikus yang dipakai mengalami trauma sehingga menyebabkan terjadinya perdarahan pada limpa.

Nekrosis bisa disebabkan oleh beberapa hal diantaranya suplai darah kurang, toksin, tidak ada inervasi syaraf, suhu, sinar radio aktif dan trauma mekanik (Berata et al., 2011), selain itu nekrosis juga bisa diakibatkan oleh virus misalnya virus distemper (Fadilah et al., 2015). Deksametason sebagai obat yang bersifat imunosupresan bekerja dengan cara menurunkan dan menghambat limfosit dan makrofag perifer, sehingga efek dari kerja deksametason tersebut menyebabkan kematian sel pada folikel limfoid (pulpa putih) limpa. Namun limfosit pada pulpa merah kurang sensitif terhadap glukokortikoid jika dibandingkan dengan pulpa putih. Glukokortikoid mempengaruhi molekul protein pada limfosit, yaitu reseptor yang terdapat pada sitoplasma di luar membran mitokondria yang menstimulasi mekanisme apoptosis. Perbedaan sensitivitas reseptor glukokortikoid ini yang mempengaruhi struktur pulpa putih pada limpa (Luzicova dan Epimova, 2009). Bila kerja apoptosis ini terus menerus terjadi maka sel limpa akan mengalami nekrosis.

Pemberian vitamin E secara oral selama 2 minggu pada tikus putih yang diberi deksametason terbukti mengalami perbaikan namun tidak signifikan pada semua perlakuan. Perbaikan yang terjadi dari nekrosis yang bersifat multifokal menjadi nekrosis bersifat fokal. Kemampuan untuk mengurangi efek deksametason ini diperoleh dari kandungan vitamin $\mathrm{E}$ yaitu tokoferol dan tokotrienol yang bersifat sebagai antioksidan (Rizvi et al., 2014). Vitamin E digabungkan dengan kilomikron (lipoprotein) di dalam dinding usus diserap secara difusi pasif, kemudian vitamin E diserap oleh sistem limfatik. Dari sistem ini vitamin $\mathrm{E}$ kemudian masuk ke dalam saluran darah untuk ditransportasikan ke hati. Kemudian hati akan memasangkan vitamin $\mathrm{E}$ ini dengan VLDL (very lowdensity lipoprotein). Selanjutnya VLDL dipecah oleh lipoprotein lipase menghasilkan LDL (low-density lipoprotein). Low-density lipoprotein (LDL) secara bebas bertukaran vitamin $\mathrm{E}$ dengan HDL (high density lipoprotein) yang kemudian bersama-sama di sirkulasi mendistribusikan vitamin $\mathrm{E}$ ke dalam jaringan. Sebagai antioksidan vitamin E dapat melindungi kerusakan membran biologis akibat radikal bebas dan mencegah kerusakan pada sel-sel normal (Aminullah et al., 2012). Vitamin E melindungi kerusakan tersebut dengan cara menghambat sel-sel yang mengalami apoptosis dan meningkatkan proliferase sel (Gheibi et al., 2013).

Pada penelitian ini didapat hasil suplementasi vitamin E per oral terhadap limpa tikus putih yang diberi deksametason $0,13 \mathrm{mg} / \mathrm{kg} \quad \mathrm{BB}$ secara subkutan mengalami perbaikan, khususnya pada dosis $150 \mathrm{mg} / \mathrm{kg} \mathrm{BB}$, dimana dari nekrosis bersifat multifokal menjadi nekrosis yang bersifat fokal. Pada dosis vitamin E $100 \mathrm{mg} / \mathrm{kg}$ BB nekrosis pada limpa belum mengalami perbaikan, dimungkinkan karena kandungan antioksidan vitamin $\mathrm{E}$ yang diberikan belum mampu menangkal radikal bebas yang dihasilkan deksametason. Untuk dosis vitamin E $200 \mathrm{mg} / \mathrm{kg}$ BB sudah terdapat limpa yang mengalami nekrosis 
fokal dan tidak mengalami nekrosis, namun tiga tikus masih mengalami nekrosis multifokal. Hal ini bisa terjadi karena vitamin E larut lemak sehingga dapat disimpan tubuh dalam jangka waktu lama dan ada kemungkinan terjadi toksisitas (Dewoto, 2009). Vitamin E yang diberikan secara berlebihan pada indukan lele mengakibatkan toksik (Mokoginta et al, 2011). Sehingga kemungkinan besar terhadap spesies lain misalkan tikus putih bisa juga menjadi toksik.

\section{SIMPULAN DAN SARAN}

\section{Simpulan}

Terjadi nekrosis multifokal pada gambaran histopatologi limpa tikus putih yang diberi deksametason $0,13 \mathrm{mg} / \mathrm{kg} \mathrm{BB}$. Pemberian vitamin E dapat memperbaiki gambaran histopatologi limpa tikus putih. Dosis vitamin E $150 \mathrm{mg} / \mathrm{kg}$ BB paling baik jika dibanding dengan dosis 100 $\mathrm{mg} / \mathrm{kg}$ BB dan $200 \mathrm{mg} / \mathrm{kg} \mathrm{BB}$.

\section{Saran}

Disarankan untuk dilakukan penelitian lanjutan mengenai mekanisme detail tentang interaksi vitamin E di limpa terhadap pemberian deksametason.

\section{UCAPAN TERIMA KASIH}

Ucapan terima kasih kepada staff laboratorium patologi dan farmakologi FKH Universitas Udayana, Balai Besar Veteriner Denpasar yang telah membantu selama penelitian ini berlangsung.

\section{DAFTAR PUSTAKA}

Aminullah Y, Wiratno, Susilaningsih N. 2012. Kombinasi Vitamin C Dan Vitamin E Dosis Tinggi Terhadap Sistem Hemapoitik Penderita Kanker Kepala Dan Leher Yang Mendapat Kemoterapi Cisplatin. J. Med. Hospitalia. 1(2): 89-94.

Berata IK, Winaya IBO, Adi AAAM, Adnyana IBW. 2011. Patologi Veteriner Umum. Denpasar: Swasta Nulus.

Bebas W, Buyona GL, Budiasa MK. 2016. Penambahan Vitamin E Pada
Pengencer BTS ${ }^{\circledR} \quad$ Terhadap Daya Hidup Dan Motilitas Spermatozoa Babi Landrace Pada Penyimpanan $15^{\circ}$ C. Bul. Vet.Udayana. 8(1): 1-7.

Brigelius-Flohe R. 1999. Vitamin E: Function and Metabolism. FASEB. Germany.

Dewoto HR. 2009. Vitamin dan Mineral. Dalam: Farmakologi Dan Terapi Edisi

5. Departemen Farmakologi Dan Terapeutik Fakultas Kedokteran Universitas Indonesia, Jakarta. Pp: 769-793.

Dhanesha M, Singh K, Bhori M, Marar T. 2015. Impact Of Antioxidant Supplementation On Toxicity Of Methotrexate: An In Vitro Study On Erythrocytes Using Vitamin E. Asian J. Pharm. and Clin. Res. 8(3): 339343.

Dharma IGBS, Berata IK, Samsuri. 2015. Studi Histopatologi Pankreas Tikus Putih (Rattus Novergicus) yang Diberi Deksametason dan Suplementasi Vitamin E. Indon. Med. Vet. 4(3): 257266.

Fadilah MF, Berata IK, Kardena IM. 2015. Studi histopatologi Limpa Anjing Penderita Distemper Dikaitkan Dengan Sebaran Sel-Sel Radang Pada Otak Dan Paru. Bul. Vet. Udayana. 7(2): 194-201.

Gheibi S, Karimipour M, Mahmoodsadeh R, Nargezi AA, Salabati M. 2013. Vitamin E Effect on Intestinal Damage in Burned Rats. J. Pharm. Sci. Tabriz University. 19(3): 83-90

Guyton AC dan Hall EJ. 1996. Buku Ajar Fisiologi Kedokteran.ed ke-9. Setawan I, Tengadi KA, Santoso A, penerjemah; Jakarta: EGC. Terjemahan dari: Textbook of Medical Physiology. Pp: 1103-1106.

Indayani SI, Susilowati, Sri RL. Pengaruh Pemberian Deksametason Terhadap Kerusakan Hepar Tikus Jantan (Rattus norvegicus) Galur Wistar. J. Online UM Ilmu Hayati 1(1).

Insani A, Berata IK, Samsuri. 2015. Studi Histopatologi Hati Tikus Putih yang 
Diberi Deksametason dan Vitamin E. Indon. Med. Vet. 4(3): 228-237.

Macfarlane DP, Fabos S, Walker BR. 2008. Glucocorticoids and fatty acid metabolism in humans: fuelling fat redistribution in the metabolic syndrome. J. Endocrinol. 197: 189204.

Kadmiel M dan Cidlowski JA. 2008. Glucocorticoid receptor signaling in health and disease. J. Trends. In Pharmacol. Sci. 34(9): 518-530.

Luzicoza EM, Evimova OA. 2009. Reaction of Bcl-2 Positive Splenic Cells to Glucocoticoids. Bul. Exp. Bio. and Med. 147(2): 257-261.

Matheos C, Lintong P, Kairupan C. 2013. Gambaran Histologik Jaringan Limpa Tikus Putih (Rattus norvegicus) Yang Diinfeksi Eschericia coli Dan Diberi Madu. J. e-Biomedik. (eBM). 1(2).

Mokoginta, Syahrizal, Zairin M. 2011. Pengaruh Kadar Vitamin E (A-
Tocopherol) Pakan Terhadap Kadar Lemak, Asam Lemak Esensial Telur Dan Derajat Tetas Telur Ikan Lele, Clarias batrachus Linn. J. Akuakultur Indonesia.

Rabiah ES, Berata IK, Samsuri. 2015. Studi Histopatologi Ginjal Tikus Putih yang Diberi Deksametason dan Vitamin E. Indon. Med. Vet. 4(3): 249256.

Rizvi S, Raza ST, Ahmad A, Abbas S, Mahdi F. 2014. The Role Of Vitamin E In Human Health And Some Disease. Sultan Qaboos University Med. J. 14(2): 157-165.

Samtani, Mahesh N, William JJ. 2005. Stability of Dexamethasone Sodium Phosphate in Rat Plasma. Int. J. of Pharm. 301:1.

Setiasih NLE, Suwiti NK, Suastika P, Piraksa IW, Susari NNW. 2011. Studi Histologi Limpa Sapi Bali. Bul. Vet. Udayana 3(1): 9-15. 